\title{
Infantile Spasm
}

National Cancer Institute

\section{Source}

National Cancer Institute. Infantile Spasm. NCI Thesaurus. Code C116529.

Seizures in the first years of life characterized by flexion and extension jerks of the neck, trunk, and extremities. 